\title{
Naphthalenothiophene Imide-Based Polymer Donor for High-Performance Polymer Solar Cells
}

Haijun Ning ${ }^{\#+}$, Gongya Zhang ${ }^{\sharp \dagger}$, Hui Chen ${ }^{\ddagger}$ Zhuoran $\mathrm{Wang}^{\dagger}$, Shaofei $\mathrm{Ni}^{\dagger}$, Fushen $\mathrm{Lu}^{\dagger}$, Fan $\mathrm{Liu}^{+}$, Li Dang ${ }^{\dagger}$, Jiangang $\mathrm{Liu}^{+}$, Feng $\mathrm{He}^{\ddagger}$, Qinghe $\mathrm{Wu}^{*+\S}$

${ }^{\dagger}$ Department of Chemistry and Key Laboratory for Preparation and Application of Ordered Structural Materials of Guangdong Province, Shantou University, Shantou, Guangdong 515063, China

${ }^{\ddagger}$ Shenzhen Grubbs Institute and Department of Chemistry Southern University of Science and Technology, Shenzhen, 518055, China

${ }^{\S}$ Department Guangdong Provincial Laboratory of Chemistry and Fine Chemical Engineering, Shantou, 515063, China 


\section{Experimental Procedures}

1. The materials characterization
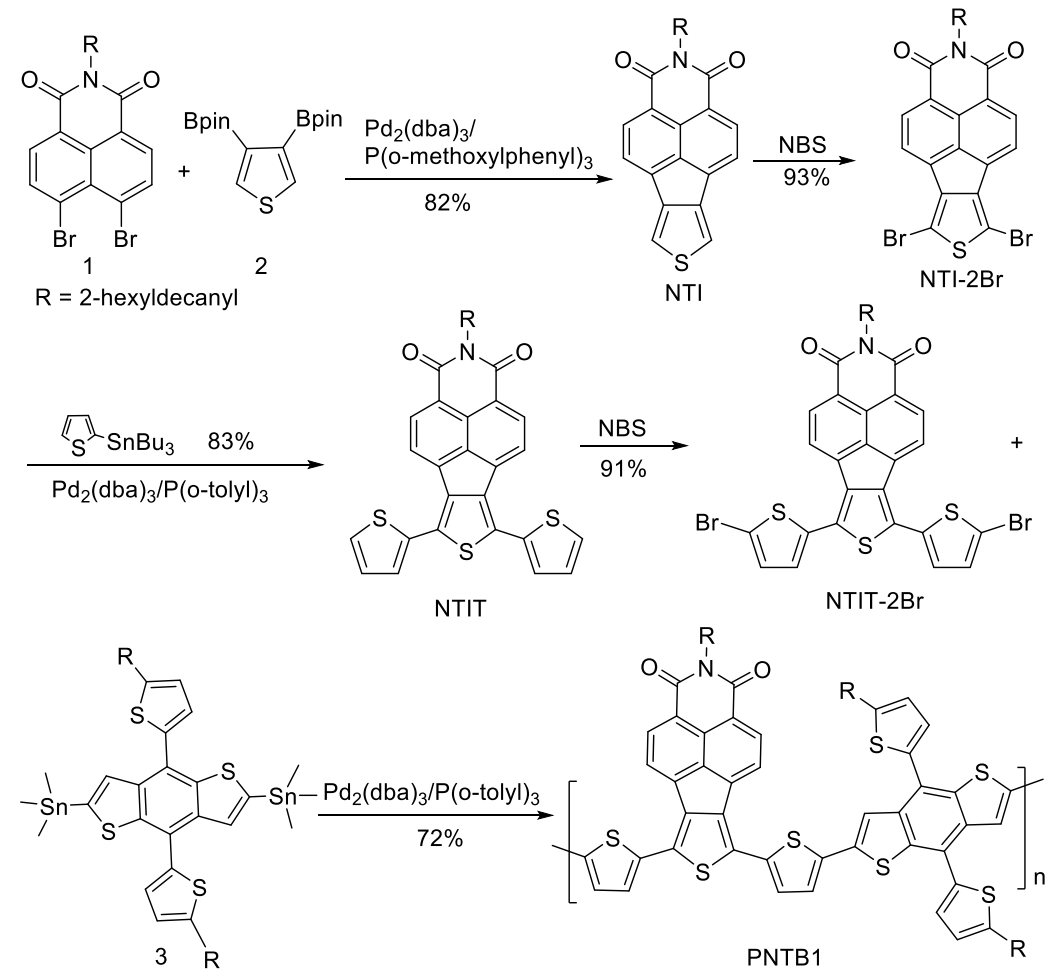

Scheme 1. The synthesis of PNTB1.<smiles>O=C1OC(=O)c2ccc3c4c(ccc1c24)C(=O)OC3=O</smiles>

(1) $\mathrm{KOH} / \mathrm{ACOH}$

(2) $\mathrm{Br}_{2} \quad 98 \%$

(3) $\mathrm{HCl}$<smiles>O=C1OC(=O)c2ccc(Br)c3c(Br)ccc1c23</smiles>

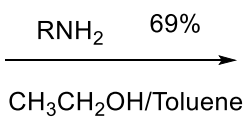<smiles>[R]N1C(=O)c2ccc(Br)c3c(Br)ccc(c23)C1=O</smiles>

$\underset{\mathrm{Et}_{3} \mathrm{~N} / \text { Toluene } 37.2 \%}{\mathrm{Br}}$

Scheme 2. The synthetic route and yield of compound 1 and 2.

The compound 1 was synthesized by two step reactions. The 4,5-dibromo-1,8naphthalenedicarboxylic anhydride ${ }^{1}$ and 4,5-dibromo-1,8-naphthalene imide $^{2}$ were prepared according to reported methods. Compounds 2 and 3 were synthesized according to literature ${ }^{3,4}$. 

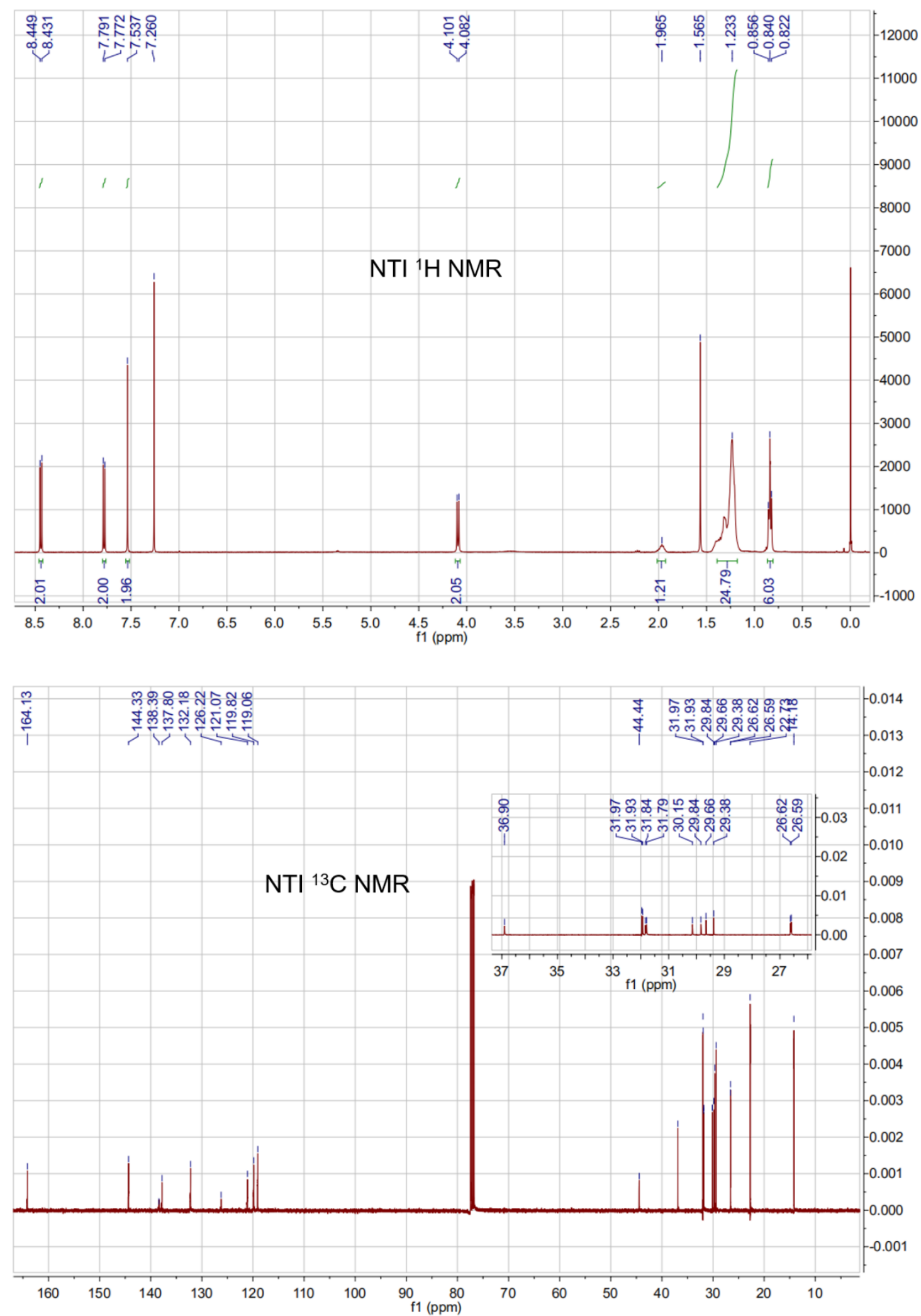

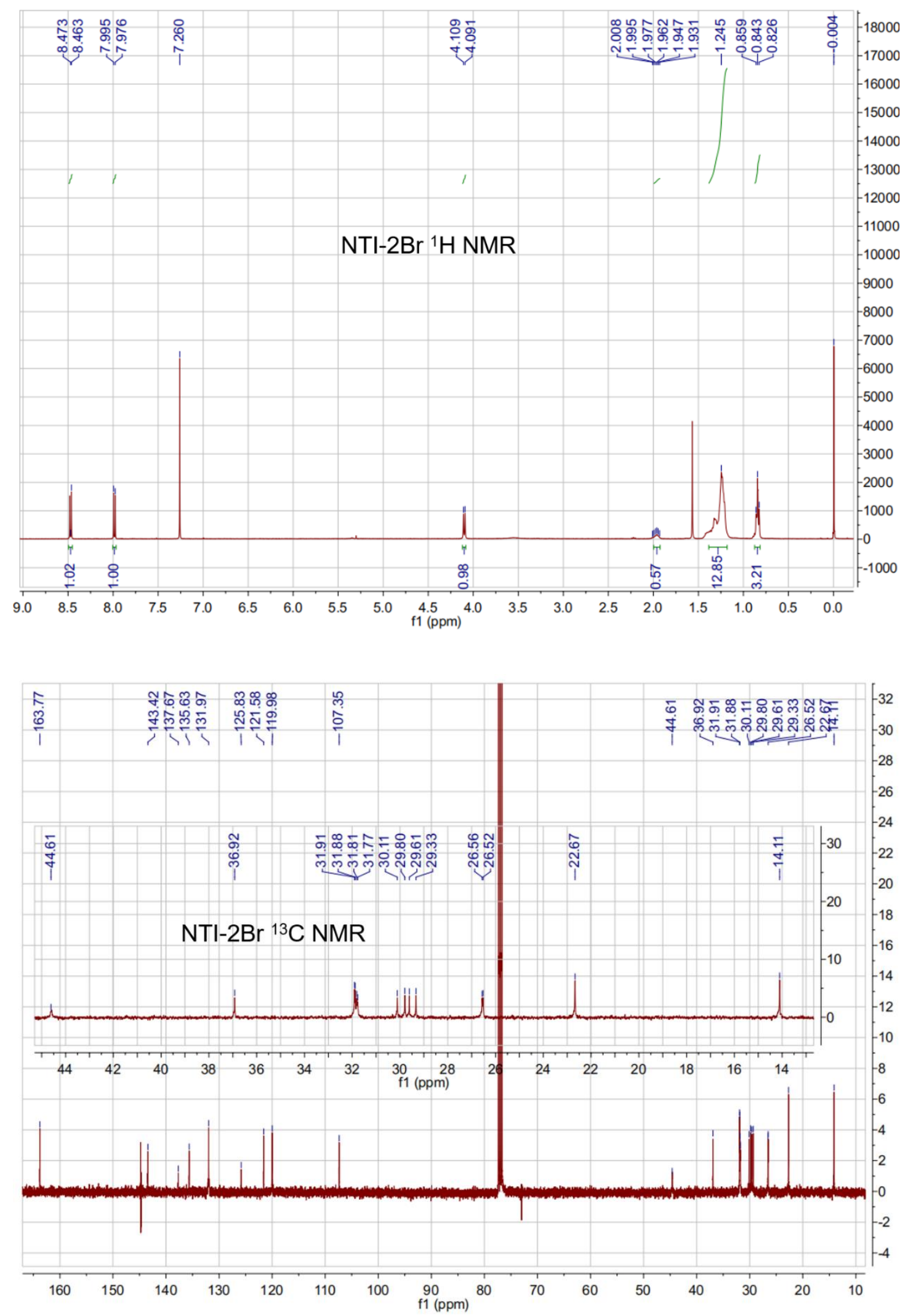

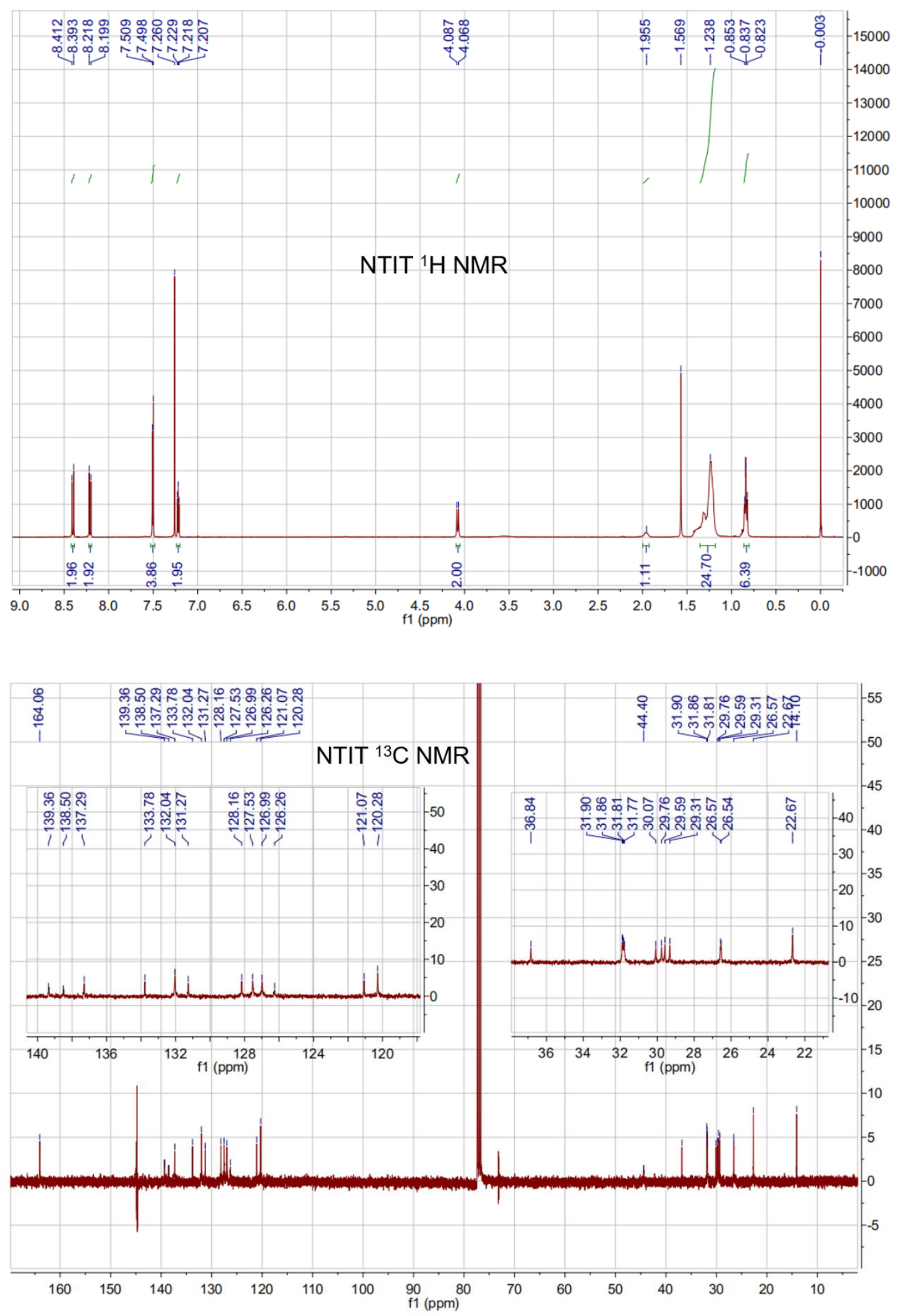

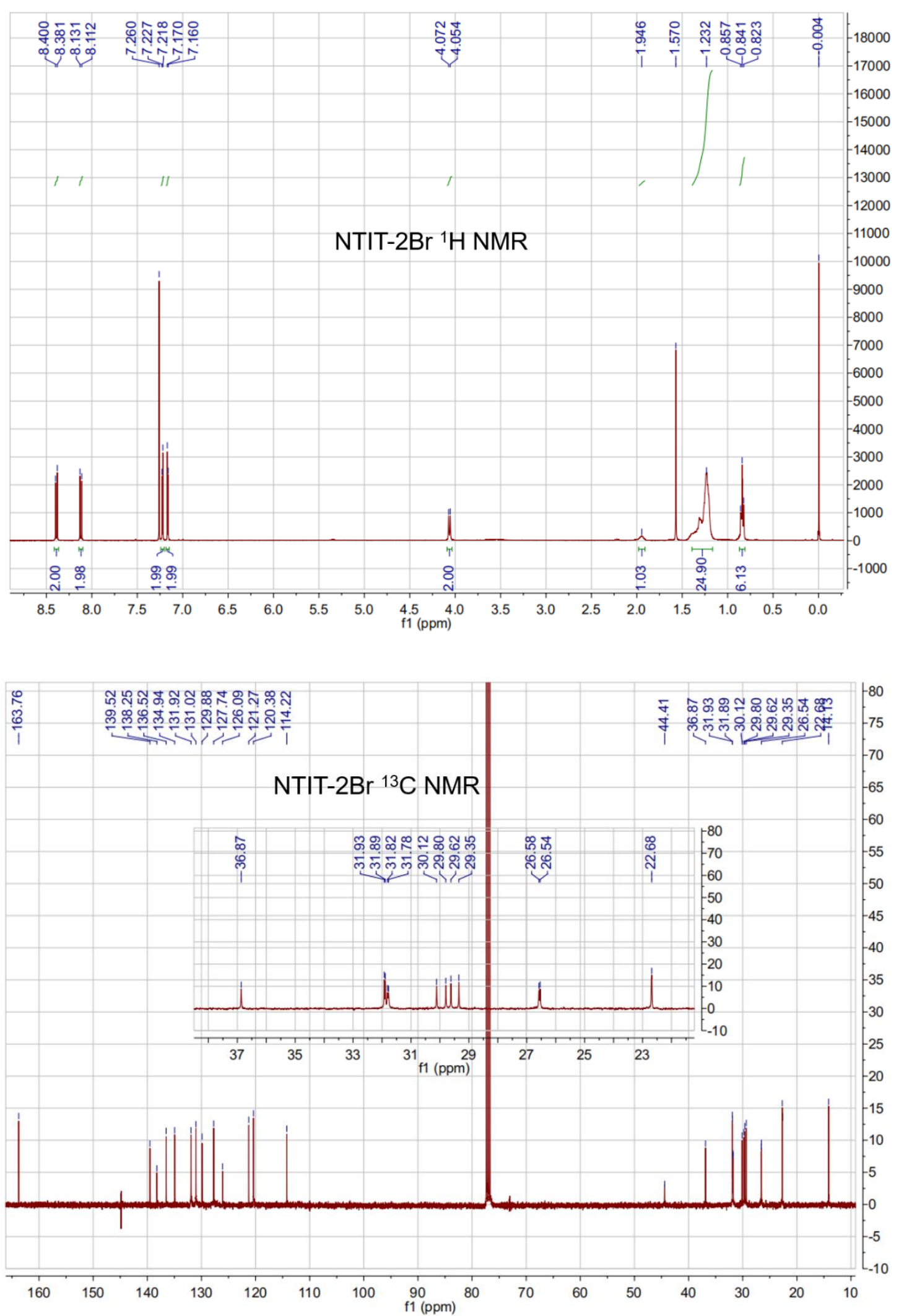


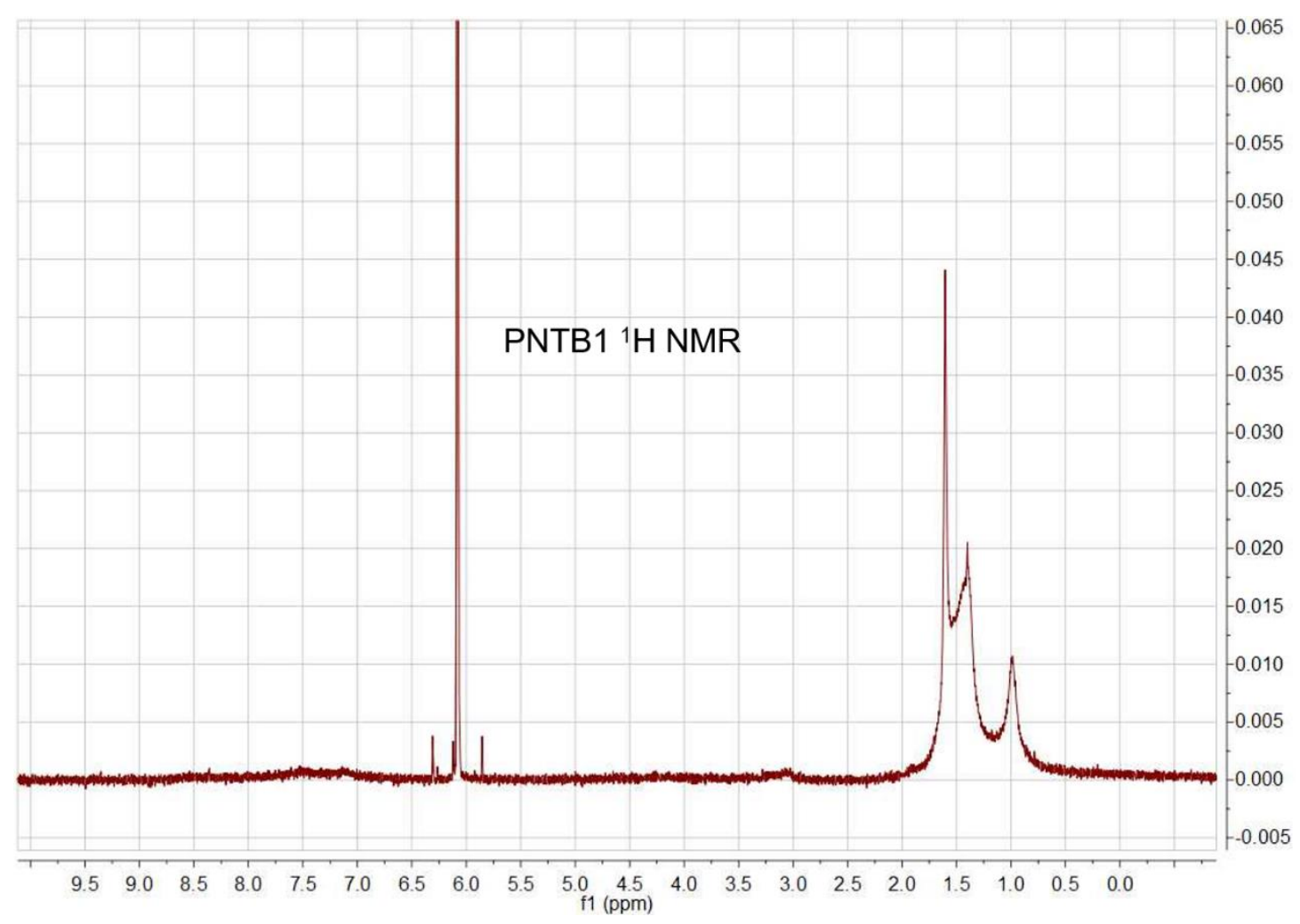

\section{Device fabrication}

Conventional solar cell devices were fabricated with the configuration of ITO/PEDOT:PSS/PNTB1:Y6/ PNDIT-F3N /Ag. The ITO glass was pre-cleaned in ultrasonic bath of dichloromethane and isopropanol, followed by UV treatment in ultraviolet-ozone cleaner (SunMonde) for $20 \mathrm{~min}$. A thin layer of PEDOT:PSS (poly(3,4-ethylene dioxythiophene): poly(styrene sulfonate)) (Clevios PVPAl 4083) was deposited on the ITO substrate by spin-coating the solution filtered through a $0.45 \mathrm{~mm}$ poly(tetrafluoroethylene) (PTFE) filter at $6,000 \mathrm{rpm}$ for $40 \mathrm{~s}$. Then, PEDOT:PSS film was baked at $150{ }^{\circ} \mathrm{C}$ for $15 \mathrm{~min}$ in the air. The active layer was prepared by spin-coating PTNB1:Y6 (D:A $=1: 1.3,19 \mathrm{mg} \cdot \mathrm{mL}^{-}$ 1 in total) solution in chloroform (CF) at $3500 \mathrm{rpm}$ for $50 \mathrm{~s}$ onto the PEDOT:PSS layer, resulting in active layer thickness of around $130 \mathrm{~nm}$ measured by Bruker Dektak $\mathrm{XT}^{*}$ profilometer. An interfacial layer of PNDIT-F3N was deposited by spin-coating solution in methanol $(0.5 \mathrm{mg} / \mathrm{ml})$. Finally, $\mathrm{Ag}(100 \mathrm{~nm})$ was thermally evaporated under a shadow mask at a chamber pressure of $\sim 2 \times 10^{-4}$ torr.

\section{Solar cell characterization.}


$J-V$ characteristics of the solar cells were measured under 1 sun, AM $1.5 \mathrm{G}$ irradiation $\left(100 \mathrm{mWcm}^{-2}\right)$ from a solar simulator with a xenon short arc lamp (USHIO INC.JAPAN). Masks with a well-defined area of $4 \mathrm{~mm}^{2}$ were used to determine the effective area of the $J-V$ measurement. Light intensity was calibrated using an NIM-certified monocrystaline silicon reference cell (\#238) with a fused silica window. Cyclic voltammetry measurements of PNTB1 and Y6 film in $25 \mathrm{mg} / \mathrm{ml}$ tetrabutyl-ammonium hexafluorophosphate solution in acetonitrile were performance by scanning $0.1 \mathrm{~V} / \mathrm{S}$ on $\mathrm{CHI600E}$ (CH Instruments Ins) with platinum working and counter electrodes, as well as a silver chloride reference electrode. UV-vis spectra were measured by using UV-Vis spectrophotometer of UV-1800PC (SHIMADZU). Active layer morphologies were investigated by using AFM (Bruker, Dimension Icon) in contacting under air condition with a $1 \times 1 \mu \mathrm{m}$ scan area. Samples for TEM measurements were prepared by spin-casting PNTB1:Y6 chloroform solution on ITO/PEDOT:PSS substrates and submerging in deionized water to make blend films float onto the air-water interface. The blend films were picked on 200 mesh copper grid for TEM measurement in JEM-F200 (JEOL). The measurement of EQE was performed by a QER3011 (Enli Technology Co. Ltd.) with a lock-in amplifier at a chopping frequency of 280 $\mathrm{Hz}$. The monochromatic light for EQE measurement was from a xenon lamp. The hole-only or electron-only devices were tested using the space charge limited current (SCLC) method, adopting the following device architectures: ITO/PEDOT:PSS/active layer/MoO$/ \mathrm{Ag}$ for holes and ITO/ZnO/active layer/PNDIT-F3N/Ag for electrons. The mobilities were obtained by taking current versus voltage plots and fitting the results to a space charge limited form. where the SCLC is defined by

$$
\mathrm{J}=\frac{9 \varepsilon_{0} \varepsilon_{r} \mu V^{2}}{8 L^{3}}
$$

Where $\varepsilon_{0}$ is the permittivity of free space, $\varepsilon_{r}$ is the relative permittivity of the material (believed to be 3), $\mu$ is the hole or electron mobility and $L$ is the thickness of the film. From the fitting curve of $\mathrm{J}$ vs $\mathrm{V}^{2}$, hole and electron mobilities can be calculated. Grazingincidence wide-angle X-ray scattering (GIWAXS) was measured at $13 \mathrm{~A}$ beam line of National Synchrotron Radiation Research Center (NSRRC, Taiwan), and were provided 
technical support by "Ceshigo Research Service, www.ceshigo.com” . All samples for GIWAXS were radiated at $12.13 \mathrm{keV} X$-ray with an incident angle of $0.10-0.15^{\circ}$.

4. Energy loss calculation:

$\Delta \mathrm{E}_{1}$ comes from the mismatch between received radiative in a narrow solid angle from sun and the omnidirectional radiative recombination. The value of $\Delta \mathrm{E}_{1}$ is only determined by $E_{g}$ for a given illumination spectrum and temperature according to Equation. The values of $\Delta \mathrm{E}_{1}$ (Table S6) were calculated to be 0.268 and $0.266 \mathrm{eV}$ for as cased and $130{ }^{\circ} \mathrm{C}$ annealed devices.

$$
\Delta E_{1}=E_{g}-q V_{O C}^{S Q}=E_{g}-k_{B} \operatorname{TIn} \frac{\int_{E_{g}}^{\infty} \Phi_{A M 1.5}(E) d E}{\int_{E_{g}}^{\infty} \Phi_{B B}(E) d E}
$$

The $\Delta \mathrm{E}_{2}$ is the radiative recombination loss from the absorption below the bandgap. To calculate $\Delta \mathrm{E}_{2}$, the Fourier-transform photocurrent spectroscopy and EL measurements were performaed for these two devices. The values of $\Delta \mathrm{E}_{2}$ were calculated to be $0.078 \mathrm{eV}$ for both devices according to Equation (2)

$$
\Delta E_{2}=q V_{O C}^{S Q}-q V_{O C}^{r a d}=k_{B} \operatorname{TIn} \frac{\int_{0}^{\infty} E Q E(E) \Phi_{B B}(E) d E}{\int_{E_{g}}^{\infty} \Phi_{B B}(E) d E}
$$

$\Delta \mathrm{E}_{3}$ is the energy loss from nonradiative recombination in devices which is calculated from the external quantum efficiency of electroluminescence $\left(E Q E_{E L}\right)$ according to the equation 3.

$$
\Delta E_{3}=q V_{O C}^{r a d}-q V_{O C}=-k_{B} \operatorname{TIn}\left(E Q E_{E L}\right)
$$



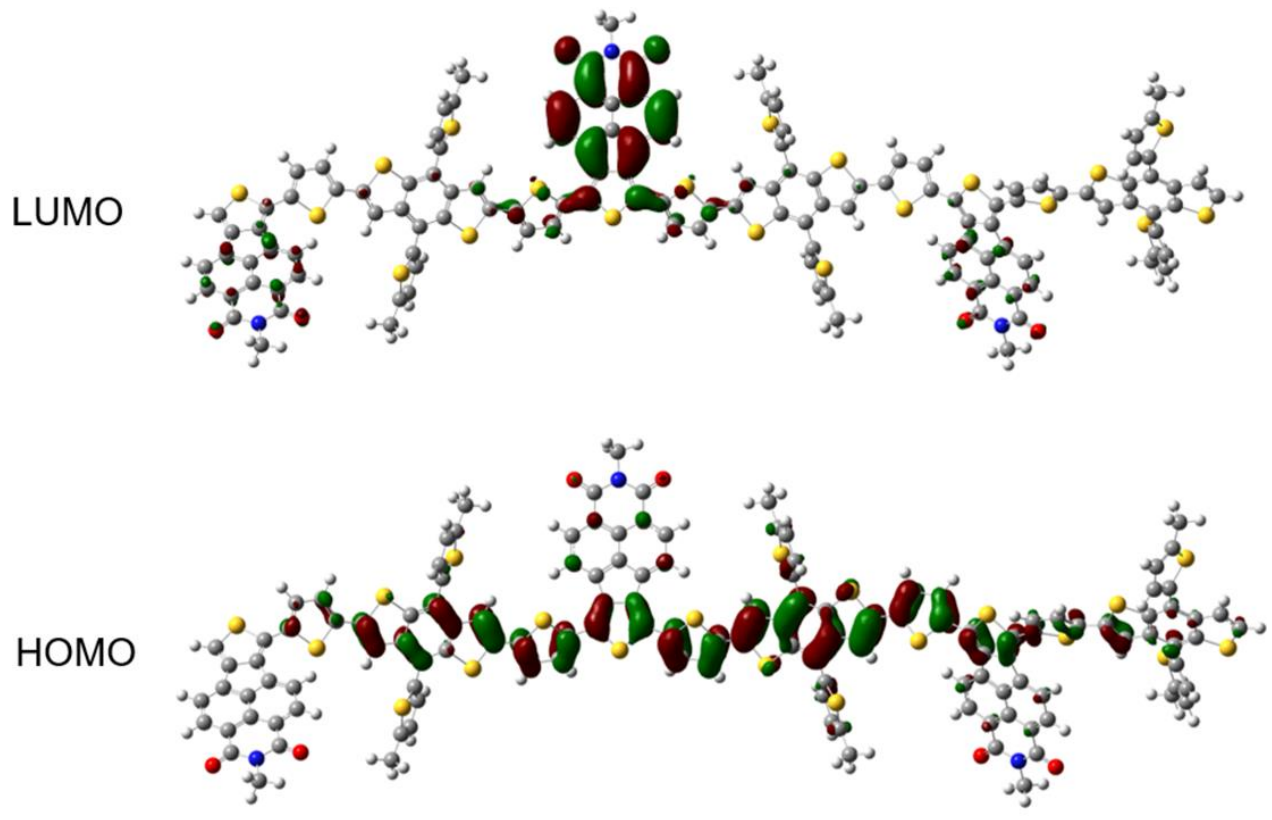

Figure S1. DFT-calculated (a) LUMO and (b) HOMO orbitals of three repeating units of PNTB1 (CAM-B3LYP / 6-31G(d)).

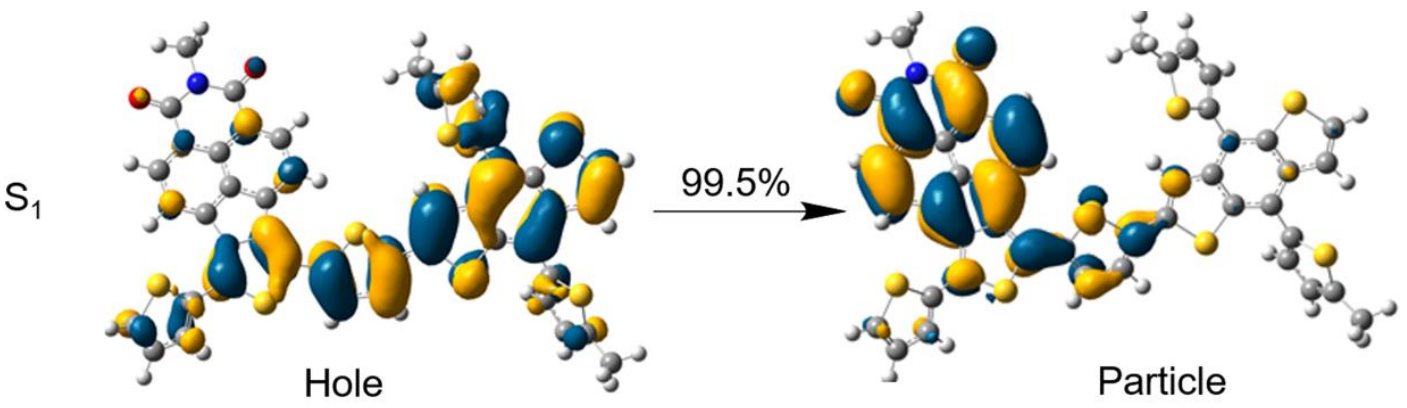

Figure S2. TD-DFT calculated natural transition orbitals (NTO) of the lowest excited singlet states of one repeating unit. The corresponding weightage of NTO $(99.5 \%)$ are listed. The calculated transitions are analysed with GaussView software. From this NTO diagram, we can see that the hole is localized on the BDT group, while the particle is localized on the NTI. And electron transfer from the BDT to NTI has the largest ratio in S1 excitation process. 

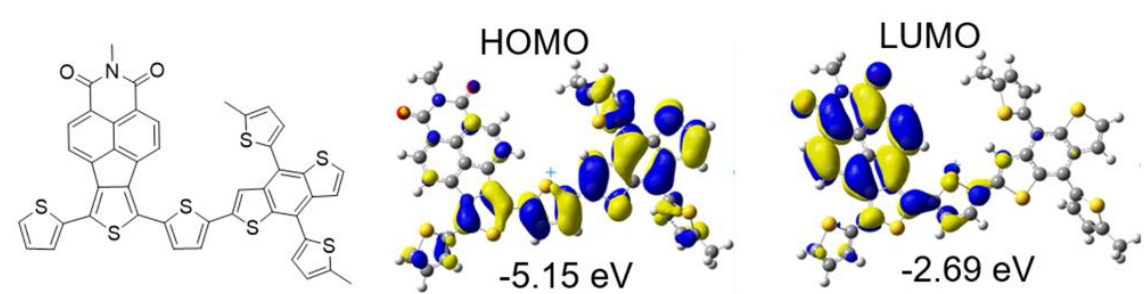

Charge Density

for BDT Unit

0.012
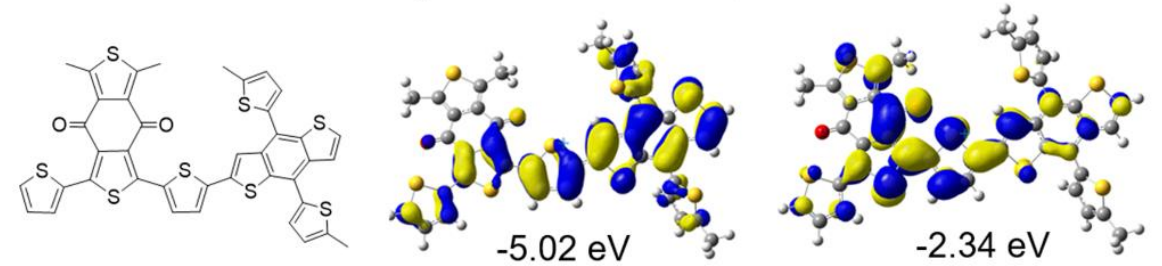

0.007
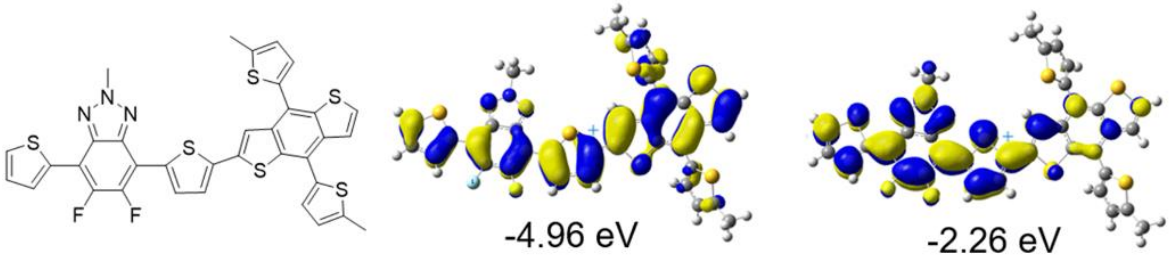

$-0.051$
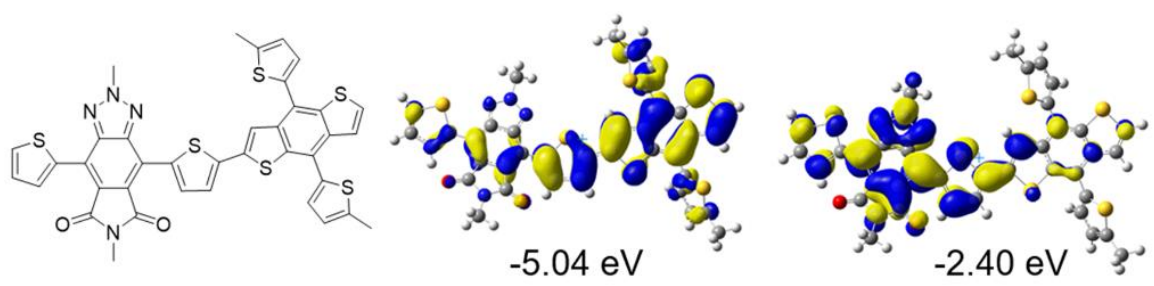

Figure S3. The LUMO/HOMO orbitals and energy levels of one repeating unit based on $\mathrm{NTI}, \mathrm{BDD}, \mathrm{BTZ}$ and TzBI; the charge density for BDT units when it is copolymerized with a NTI, BDD, BTZ and TzBI. All the geometries were optimized by using the B3LYP functional ${ }^{5,6}$ with the Gaussian 09 program (Frisch, M. J. et. al. Wallingford CT, 2009.). The 6-31G(d) basis set $^{7}$ was used for the calculations. M06-2X functional ${ }^{8}$ with Multiwfn program $^{9}$ was used for the analysis of the charge density of the BDT fragment. The charge density of the BDT unit coupled with NTI have highest value which suggests NTI has higher electron-withdrawing ability than BDD and BTZ, and TzBI. 


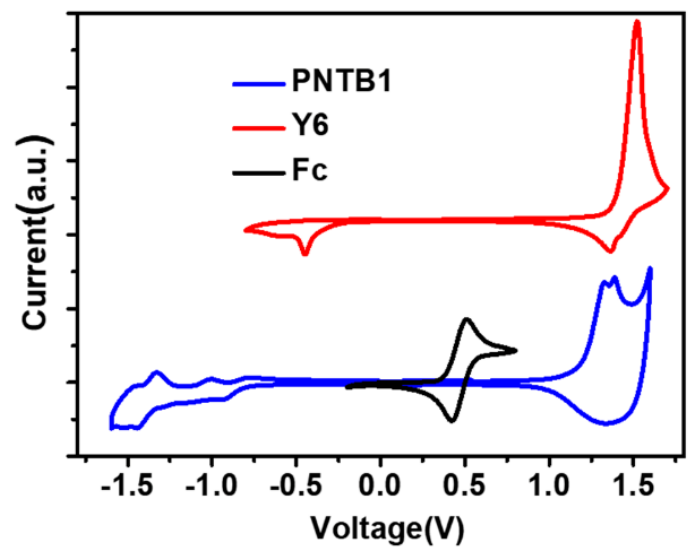

Figure S4. The cyclic voltammograms of the films of PNTB1 and $\mathrm{Y} 6$ with $\mathrm{Fc} / \mathrm{Fc}^{+}$as the reference.

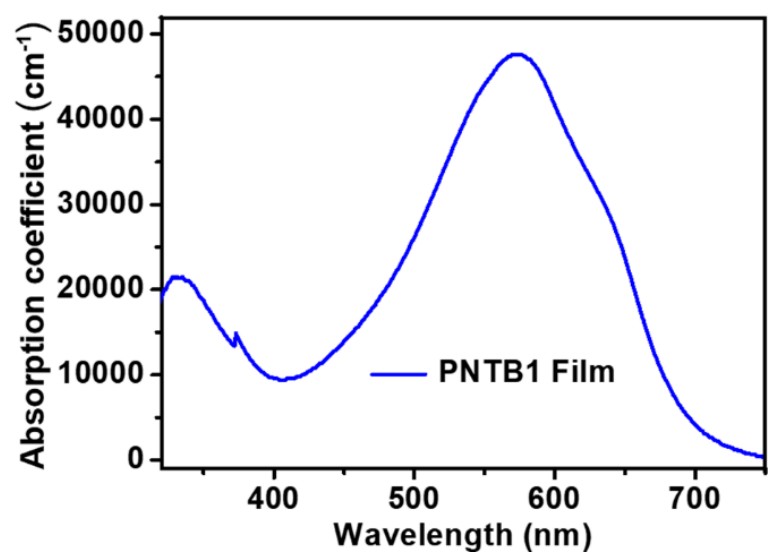

Figure S5. The film absorption of PNTB1 in absolute scale.

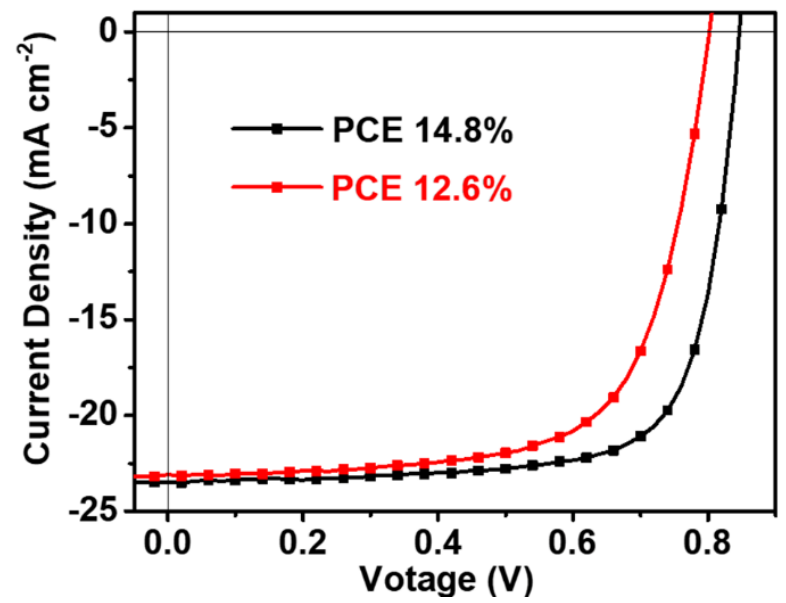

Figure S6. The stability of the OPV device based on PNTB1/Y6. After storage of the device that gives the PCE of $14.8 \%$ for 208 days in $\mathrm{N}_{2}$ atmosphere, the PCE value decreased by $17 \%$ to the value of $12.6 \%$. 

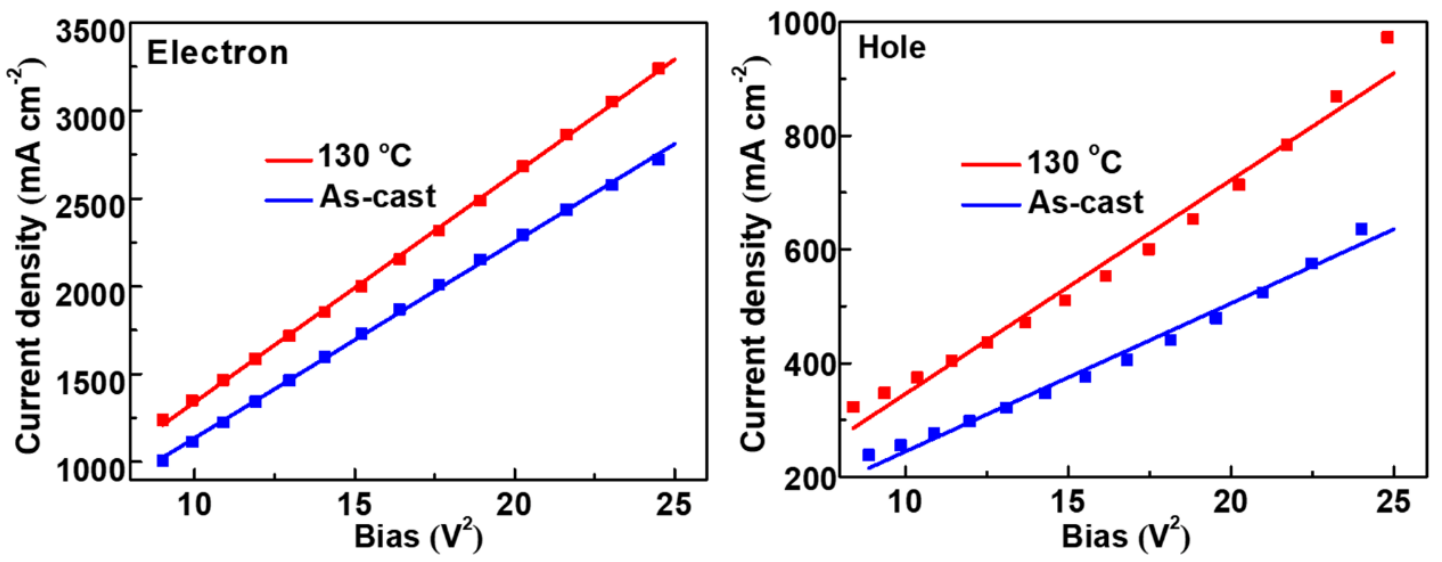

Figure S7. Electron and hole mobility for as-cast and $130{ }^{\circ} \mathrm{C}$ annealed blend films of PNTB1:Y6.
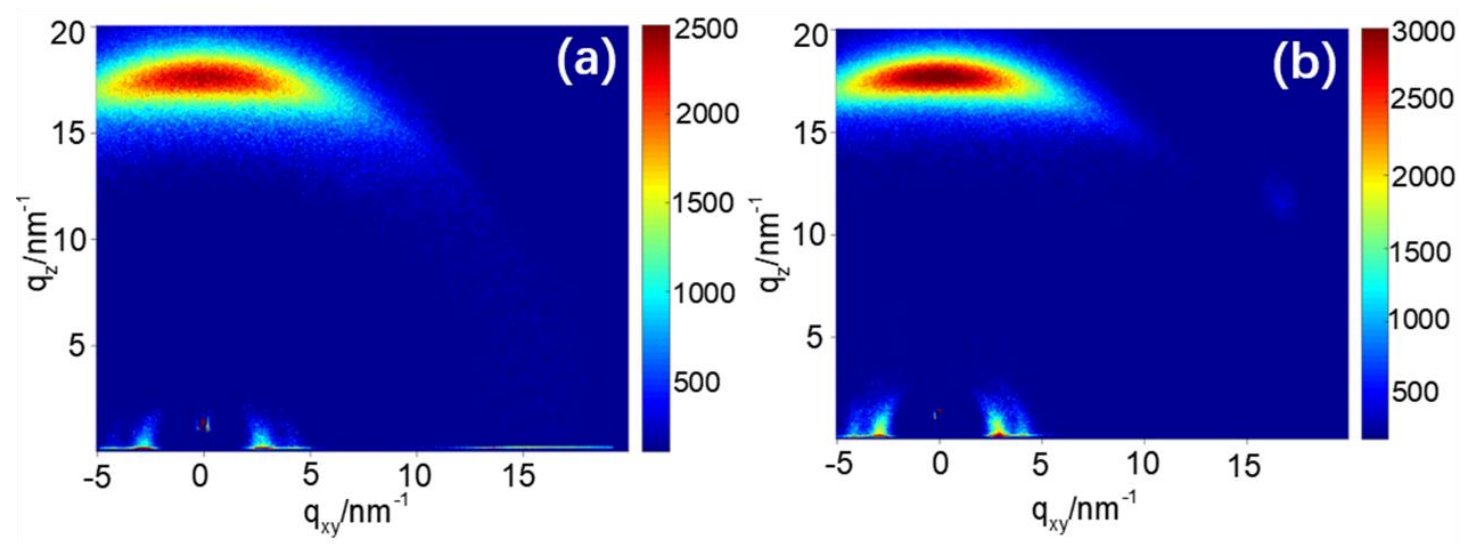

Figure S8. GIWAXS patterns of films on PEDOT:PSS-modified Si substrates. (a) neat Y6 film; (b) neat $Y 6$ film annealed at $130{ }^{\circ} \mathrm{C}$;

Table S1. J-V characteristics of solar cell devices of PNTB1:Y6 at different annealing temperature.

\begin{tabular}{ccccc}
\hline $\begin{array}{c}\text { Annealing } \\
\left({ }^{\circ} \mathrm{C}\right)\end{array}$ & $\operatorname{Voc}(\mathrm{V})$ & $\begin{array}{c}J_{s c} \\
\left(\mathrm{~mA} \mathrm{~cm}^{-2}\right)\end{array}$ & $\mathrm{FF}$ & PCE $(\%)$ \\
\hline As-cast & $0.87 \pm 0.01$ & $22.28 \pm 0.22$ & $0.69 \pm 0.01$ & $13.44 \pm 0.20(13.64)$ \\
$110{ }^{\circ} \mathrm{C}$ & $0.86 \pm 0.01$ & $22.77 \pm 1.04$ & $0.73 \pm 0.01$ & $14.39 \pm 0.45(14.85)$ \\
$130{ }^{\circ} \mathrm{C}$ & $0.83 \pm 0.01$ & $24.64 \pm 0.57$ & $0.72 \pm 0.01$ & $14.58 \pm 0.61(15.18)$ \\
$150{ }^{\circ} \mathrm{C}$ & $0.82 \pm 0.01$ & $25.36 \pm 0.23$ & $0.68 \pm 0.02$ & $14.13 \pm 0.39(14.52)$
\end{tabular}

The PCEs were obtained for over 10 devices 
Table S2. PNTB1:IT-4F based solar cells with device configuration of ITO/ZnO/blends $/ \mathrm{MoO}_{3} / \mathrm{Ag}$ was fabricated with total concentration of $(20 \mathrm{mg} / \mathrm{ml}, 1: 1.25)$ in O-xylene.

\begin{tabular}{ccccc}
\hline $\begin{array}{c}\text { DIO Volume } \\
(\%)\end{array}$ & $V_{\text {OC }}(\mathrm{V})$ & $\begin{array}{c}J_{S C} \\
\left(\mathrm{~mA} \mathrm{~cm}^{-2}\right)\end{array}$ & $\mathrm{FF}$ & $\mathrm{PCE}(\%)$ (best) \\
\hline 0 & $0.84 \pm 0.00$ & $14.66 \pm 0.82$ & $0.63 \pm 0.02$ & $7.92 \pm 0.36(8.27)$ \\
1.25 & $0.86 \pm 0.02$ & $17.39 \pm 0.89$ & $0.71 \pm 0.02$ & $10.66 \pm 0.1(10.83)$ \\
2 & $0.86 \pm 0.00$ & $12.58 \pm 1.38$ & $0.66 \pm 0.02$ & $7.11 \pm 0.95(8.07)$ \\
\hline
\end{tabular}

The PCEs were obtained for over 10 devices

Table S3. Electron and hole mobility of different blend films of PNTB1:Y6.

\begin{tabular}{ccccccc}
\hline Films & $\begin{array}{c}\text { Thickness } \\
(\mathrm{nm})\end{array}$ & \multicolumn{2}{c}{ Slope-K } & $\begin{array}{c}\mu_{\mathrm{e}} \\
\left(\mathrm{cm}^{2} \cdot \mathrm{V}^{-1} \cdot \mathrm{s}^{-1}\right)\end{array}$ & $\begin{array}{c}\mu_{\mathrm{h}} \\
\left(\mathrm{cm}^{2} \cdot \mathrm{V}^{-1} \cdot \mathrm{s}^{-1}\right)\end{array}$ & $\mu_{\mathrm{e}} / \mu_{\mathrm{h}}$ \\
\cline { 3 - 4 } & 130 & 112.4 & 26.1 & $8.20 \times 10^{-4}$ & $1.92 \times 10^{-4}$ & 4.27 \\
\hline As-cast & 130 Electron & Hole & & & & \\
$130{ }^{\circ} \mathrm{C}$ & 130 & 130.0 & 37.6 & $9.56 \times 10^{-4}$ & $2.76 \times 10^{-4}$ & 3.46 \\
\hline
\end{tabular}

Table S4. The d-spacing and crystal coherence length of as-cast and $130^{\circ} \mathrm{C}$ neat polymer films of PNTB1

\begin{tabular}{ccccc}
\hline PNTB1 & d-spacing $(100)(\AA)$ & $d$-spacing $(010)(\AA)$ & FWHM $\left(\AA^{-1}\right)$ & $\operatorname{CCL}(\mathrm{nm})$ \\
\hline As-cast & 30.49 & 3.63 & 0.23 & 24.57 \\
$130{ }^{\circ} \mathrm{C}$ & 30.49 & 3.62 & 0.18 & 31.40 \\
\hline
\end{tabular}


Table S5. The crystal coherence length of as-cast and $130^{\circ} \mathrm{C}$ annealed blend films of PNTB1:Y6

\begin{tabular}{cccc}
\hline PNTB1:Y6 & Peak location $\left(\AA^{-1}\right)$ & FWHM $\left(\AA^{-1}\right)$ & CCL $(\mathrm{nm})$ \\
\hline As-cast & 1.761 & 0.22 & 25.69 \\
$130{ }^{\circ} \mathrm{C}$ & 1.762 & 0.19 & 29.75 \\
\hline
\end{tabular}

Table S6. Detailed Eloss of the PNTB:Y6, PNTB-2T:Y6 and PNTB-2T:Y6:PC71BM based devices.

\begin{tabular}{cccccc}
\hline Devices & $\mathrm{E}_{\mathrm{g}}(\mathrm{V})$ & $\Delta \mathrm{E}(\mathrm{eV})$ & $\Delta \mathrm{E}_{1}(\mathrm{eV})$ & $\Delta \mathrm{E}_{2}(\mathrm{eV})$ & $\Delta \mathrm{E}_{3}(\mathrm{eV})$ \\
\hline As-cast & 1.450 & 0.575 & 0.268 & 0.078 & 0.226 \\
$130{ }^{\circ} \mathrm{C}$ & 1.425 & 0.590 & 0.266 & 0.079 & 0.241 \\
\hline
\end{tabular}

\section{Refereneces}

(1) Uersfeld, D.; Stappert, S.; Li, C.; Müllen, K.; Practical Syntheses of Terrylene Chromophores from Naphthalene and Perylene Building Blocks. Adv. Synth. Catal. 2017, 23, 4184-4189.

(2) Sun, Z.; Wu, J.; 7,14-Diaryl-Substituted Zethrene Diimides as Stable Far-Red Dyes with Tunable Photophysical Properties. J. Org. Chem. 2013, 78, 9032-9040.

(3) Kise, K.; Chen, F.; Kato, K.; Tanaka, T.; Osuka, A.; Cyclic Hybrids of Alternately Linked 2,5-Pyrrolylenes and 3,4-Thienylenes. Chem. Lett. 2017, 46, 1319-1322.

(4) Zhou, J.; Zuo, Y.; Wan, X.; Long, G; Zhang, Q.; Ni, W.; Liu, Y.; Li, Z.; He, G.; Li, C.; Kan, B.; Li, M.; Chen, Y.; Solution-Processed and High-Performance Organic Solar Cells Using Small Molecules with a Benzodithiophene Unit. J. Amer. Chem. Soc., 2013, 135, 8484-8487.

(5) Becke A. D., Density-functional Thermochemistry. III. The Role of Exact Exchange J. Chem. Phys., 1993, 98, 5648-5652

(6) Stephens P. J.; Devlin F. J.; Chabalowski C. F.; Frisch M. J., Ab Initio Calculation of Vibrational Absorption and Circular Dichroism Spectra Using Density Funtional Force 
Fields, J. Phys. Chem., 1994, 98, 11623-11627.

(7) Petersson G. A.; Bennett A.; Tensfeldt T. G.; Al-Laham M. A.; Shirley W. A.; Mantzaris J. A., A Complete Basis Set Model Chemistry. I. The Tolal Energies of Closed-shell Atoms and Hydrides of the first-row Elements J. Chem. Phys., 1988, 89, 2193-2218.

(8) Zhao Y.; Truhlar D. G.; A New Local Density Functional for Main-group Thermochemistry, Transition Metal Bonding, Thermochemical Kinetics, and Noncovalent Interactions. J. Chem. Phys., 1994, 125, 194101.

(9) Lu T.; Chen F.; Multiwfn: A Multifunctional Wavefunctional Analyzer J. Comput. Chem., 2012, 33, 580-592. 